Mgr Małgorzata Kulikowska

UMCS Lublin

e-mail: kulikowska.malgorzata@gmail.com

\title{
«Утрачена связь времен, связь культур...»- память об Осипе Мандельштаме в жизни и творчестве Варлама Шаламова ${ }^{1}$
}

Размышляя над взаимоотношением памяти и культуры, выдающийся русский литературовед, семиотик и культуролог Юрий Лотман (1922-1993), в кратком очерке Память в культурологическом освещении (1985) утверждал, что культура - это «коллективная п а м я ть [подчеркнуто мною - М. К.], то есть индивидуальный механизм хранения и передачи некоторых сообщений (текстов) и выработки новых» ${ }^{2}$. Из этого следует, что память ${ }^{3}$ является необходимой составляющей хода культуры и ее развития, поскольку смыслы не просто хранятся в ней, а, наоборот, - «растут» ${ }^{4}$, то есть трансформируются в новых контекстах, приобретая новое значение. В статье Память культуры (1986) исследователь подробно объяснил, в чём состоит суть хранения прошлого:

прошлые состояния культуры постоянно забрасывают в ее будущее свои обломки: тексты, фрагменты, отдельные имена и памятники. Каждый из этих элементов имеет

1 Druk publikacji został sfinansowany przez Uniwersytet Marii Curie-Skłodowskiej w Lublinie w ramach grantu Wydziału Humanistycznego (Публикация статьи осуществляется при поддержке Университета Марии Кюри-Склодовской в Люблине в рамках гранта филологического факультета).

2 Ю.М. Лотман, Память в культурологическом освещеени, [в:] idem, Семиосфера, Санкт-Петербург 2010, с. 673.

3 В памяти проявляется не только прошлое культуры, но прошлое как таковое как одно из трех измерений времени. Августин Блаженный в работе Исповедь (397-401) утверждал, что время имеет субъективный характер: «настоящее прошедшего проявляется как память, настоящее настоящего - созерцание, настоящее будущего - ожидание [перевод мой - М. К.]». См. Św. Augustyn, Wyznania, пер. Z. Kubiak, Kraków 2013, c. 356.

4 Ю.М. Лотман, ор. cit., с. 675. 
свой объем «памяти», каждый из контекстов, в который он включается, актуализирует некоторую степень его глубины 5 .

Таким образом, по мнению тартуского ученого, память представляет собой не что иное, как «св язь культур [подчеркнуто мною - М. К.]» ${ }^{6}$. Такой подход, на наш взгляд, полностью разделял и Варлам Шаламов ${ }^{7}$, который употребил процитированное определение («связь культур») для истолкования своего понимания понятия «память», в частности, в отношении «отдельных имен» ${ }^{8}$ русской литературы начала XX века. «Утрачена связь времен, связь культур [подчеркнуто мною - М. К.] - преемственность разрублена, и наша задача восстановить, связать концы этой нити» ${ }^{9}-$ именно об этом автор Кольмских рассказов сообщал в одном из первых своих писем Надежде Яковлевне Мандельштам ${ }^{10}$ - вдове поэта Осипа Эмильевича Мандельштама, с которой вел переписку с 29 июня 1965 года по 21 июля 1968 года. Важно обратить внимание на то, что между процитиворанными словами Шаламова наблюдается интертекстуальная связь со словами шекспировского Гамлета, который в конце первого акта трагедии произносит:

The time is out of joint. O cursed spite,

That ever I was born to set it right! ${ }^{11}$

В русской культуре XX века эти слова были хорошо известны в переводе Андрея Кронеберга, в контексте которых шаламовская аллюзия на Шекспира становится вполне очевидной:

5 Ю.М. Лотман, Память культуры, [в:] idem, Семиосфера..., с. 621.

6 Ibidem, c. 620.

7 Любопытно добавить, что Шаламов переписывался с Юрием Лотманом, а его научные исследования называл «крайне важной деятельностью», о чем свидетельствует хотя бы письмо Шаламова Лотману (к сожалению, дата письма не сохранилась), в котором автор Кольммских рассказов (1978) предлагал свое «участие в тартуском сборнике». См. В. Шамалов, Переписка с Ю. М. Лотманом, [в:] idem, Собрание сочинений в шести томах, т. 6, сост. И. Сиротинская, Москва 2013, с. 594.

8 См. прим 5.

9 В. Шаламов, Переписка с Н. Я. Мандельштам, [в:] idem, Собрание сочинений..., T. 6 , c. 412 .

10 См. подробное жизнеописание Надежды Мандельштам: П. Нерлер, Свидетельнииа поэзии. Очерк жизни и творчества Надежды Мандельштам, „Вопросы литературы” 2014, № 3, c. 258-323.

11 W. Shakespeare, Hamlet, London: Penguin Books 1994, p. 54-55. 
Распалась связь времен.

Зачем же я связать ее рожден? ${ }^{12}$

Как видим, гамлетовскую задачу - соединения распавшейся связи времен - Шаламов возлагает на поэтов, к которым причисляет и себя.

Если более подробно взглянуть на отношение Шаламова к Надежде Мандельштам, то видно, что он многократно подчеркивал ее роль в восстановлении культурного процесса в России, чрезвычайно высоко оценивая рукопись Воспоминаний как «любопытнейшего явления и с тор и и [подчеркнуто мною - М. К.] русской поэзии» ${ }^{13}$ (на самом деле Воспоминания ${ }^{14}$ являются картиной русской интеллигенции начала двадцатого столетия). Схожее мнение о Надежде Мандельштам не только как о писательнице, но и жене, которая смогла сохранить архив мужа, высказал лауреат Нобелевской премии Иосиф Бродский, признавая ее женщиной «способной замедлить, если не предотвратить в конечном счете культурный распад нации [подчеркнуто мною - М. К.]» ${ }^{15}$. Важно добавить и то, что Варлам Шаламов одним из первых прочел рукопись воспоминаний Надежды Мандельштам наряду с таким мастером поэтического творчества, как Анна Ахматова, что следует понимать как знак глубочайшего доверия к Шаламову со стороны мемуаристки ${ }^{16}$. Автор Четвертой Вологды (1968-1971), в свою очередь, посвятил вдове Мандельштама стихотворение Таруса (1964) и рассказ Сентенция (1965), завершающий сборник Левый берег.

Варлам Шаламов во многих статьях и заметках обращал внимание на трагедию русских поэтов и писателей, о судьбах которых идет речь в книге вдовы Мандельштама. В эссе Русские поэты и десталинизация. Маяковский (1964) он назвал «имена нарочито забываемые, как будто двадцатый век русской поэзии не существовал» ${ }^{17}$, а именно: Иннокентия Анненского, Анны Ахматовой, Константина Бальмонта, Андрея Белого, Александра Блока, Максима Волошина, Николая Гумилева, Сергея Есенина, Михаила Кузмина, Бориса Пастернака, Игоря Северянина, Марины Цветаевой и других.

Как известно, в сталинскую эпоху «забытие» осуществлялось путем уничтожения поэтов не только в прямом смысле, но и путем уничтожения памяти о

12 Цит. за: Вяч. Иванов, Шекспир и Сервантес, [в:] idem, Собрание сочинений в чеmырех томах, т. 4, Брюссель 1987, с. 105.

13 В. Шаламов, Переписка с Н. Я. Мандельштам ..., с. 409.

14 См. Н.Я. Мандельштам, Воспоминания, Москва 1987.

15 И. Бродский, Надежда Мандельштам (1899-1980). Некролог, [в:] idem, Власть стихий. Эссе, Санкт-Петербург 2012, с. 52.

16 П. Нерлер, Свидетельница поэзии ..., с. 299.

17 В. Шаламов, Русские поэты и десталинизация. Маяковский, [в:] idem, Собрание сочинений..., т. 5, с. 66. 
них в коллективном сознании. Яркий пример здесь - судьба Осипа Мандельштама (в некоторой степени предвиденная им самим), в теоретических статьях которого, как и у Шаламова, звучит громкий голос о крушении культуры в ХХ веке. К примеру, в эссе Слово и культура (1921) поэт утверждал:

культура стала военным лагерем: у нас не еда, а трапеза; не комната, а келья; не одежда, а одеяние [...]. Современник не знает только физического голода, только духовной пищи ${ }^{18}$.

Говоря, что «старый мир - не от мира сего» ${ }^{19}$, поэт подчеркивал резкое различие между настоящим и прошлым именно из-за отсутствия культурной связи. Одной из важнейших задач, поставленных перед поэзией, Осип Мандельштам считал упомянутое выше гамлетовское «восстановление связи» между «старым» и «новым» порядками, то есть восстановление культуры, которое должно осуществиться вследствие восстановления течения времени: «поэзия - плуг, взрывающий время так, что глубинные слои времени, его чернозем, оказываются сверху» ${ }^{20}$. Виктор Вердинских справедливо замечает, что в этом контексте Осип Мандельштам как автор теоретических статей, с одной стороны, и говорящий субъект его лирических произведений, с другой, составляют единое целое, поскольку они оба «ворочают огромными губами времени, мыслят веками и эпохами» ${ }^{21}$, предчувствуя наступающую трагическую гибель культуры, жертвой которой, к сожалению, стал сам автор сборника Камень (1913).

Варлам Шаламов принадлежал к той «узкой - по словам Виктора Вердинских - кучке знатоков-эрудитов, близких литераторов и просто интеллектуалов» ${ }^{22}$, которым еще в двадцатые годы не было чуждо творчество Мандельштама. Это вполне понятно, поскольку автор Кольлмских рассказов принимал активное участие в культурной жизни Москвы того времени и превосходно разбирался в литературе ${ }^{23}$, поэтому особое отношение к Осипу Мандельштаму с его стороны было продуманным и глубоко обоснованным.

18 О. Мандельштам, Слово и культура, [в:] Слово и культура. О поэзии. Разговор о Данте. Статьи. Рецензии, сост. П. Нерлер, Москва 1987, с. 40.

19 Ibidem, c. 40.

20 Ibidem.

21 В. Вердинских, История советской поэзии, Москва 2014, с. 77.

22 Ibidem, c. 82.

23 Варлам Шаламов дал свидетельство блестящего знания русской литературы начала XX века в нескольких статьях. См. В. Шаламов, Двадиатые годы. Заметки студента МГУ. Начало, „Юность” 1987, № 11, с. 37-45; idem, Двадиатые годы. Заметки студента МГУ. Окончание, „Юность” 1987, № 12, с. 28-37; idem, Москва 20-30-х годов, [в:] idem, Собрание сочинений..., т. 4, с. 420-422. 
Исследователь литературного творчества автора Шума времени Павел Нерлер отмечает, что Шаламова и Мандельштама «свела не жизнь, а смерть» ${ }^{24}$ - оба были узниками ГУЛага, откуда второй никогда не вернулся ${ }^{25}$. Как известно из биографии Мандельштама, он, как и Шаламов, был одной из многочисленных жертв сталинских репрессий. Впервые он был арестован в мае 1934 года за стихотворение Mы живем, под собою не чуя страны, которое написал осенью 1933 года. Впоследствии был отправлен в Воронеж, где три года работал в газетах и журналах. После окончания первого срока ему не разрешили поселиться в Москве, поэтому он жил в Калинине. В 1938 году поэт был вторично арестован под предлогом контрреволюционной деятельности и осужден к пяти годам ссылки на Колыме, где умер 27 декабря 1938 года в больничном бараке в пересыльном лагере на Второй речке. С момента первого ареста Мандельштама в Советском Союзе почти двадцать лет его произведения не публиковались. Только в шестидесятые годы стихи были заново опубликованы, благодаря усилиям жены и ее друзей.

Шаламов узнал о трагической смерти гениального поэта от Нины Владимировны Савоевой, которая в то время работала врачом в лагерном медпункте. Двадцать лет спустя, после возвращения с Колымы, писатель посвятил смерти Мандельштама рассказ Шерри-бренди, написанный в 1954 году и вошедший в сборник Колымские рассказы. Следует уточнить, что изначально рассказ существовал под названием Смерть поэта.

Писатель прочел рассказ на вечере памяти Осипа Маньдельштама, организованном Ильей Эренбургом 13 мая 1965 года на механико-математическом факультете МГУ, где собрался широкий круг любителей поэзии. Чтению рассказа предшествовало небольшое вступление самого автора, в котором он говорил о Мандельштаме и об акмеизме (содержание выступления сохранилось, благодаря драматургу и мемуаристу Александру Гладкову $\left.{ }^{26}\right)$.

В начале выступления Шаламов сказал:

Речь идет о воскрешении Мандельштама. Мандельштам никогда не умирал. Речь идет не о том, что постепенно время ставит всех на свои места. События, идеи и люди находят свои истинные масштабы ${ }^{27}$.

24 П. Нерлер, Сила жизни и смерти. Варлам Шаламов и Мандельштамы (на полях переписки Н. Я. Мандельштам и В. Т. Шаламова), „Оsteuropa” 2007, № 6, с. 229.

25 См. Осип Мандельштам. Хронология, www.mandelshtam.velchel.ru (09.08.2014).

26 См. В. Есипов, Шаламов, Москва 2012, с. 266.

27 В. Шаламов, <О Мандельштаме>, [в:] idem, Собрание сочинений..., т. 5, с. 209. 
Таким образом, мысли Шаламова были сосредоточены вокруг проблемы возвращения в общественное сознание памяти о гениальном поэте ${ }^{28}$, что в некоторой степени можно считать символом постепенного возвращения русских поэтов начала двадцатого столетия в официальный обиход, то есть, повторяя за самим автором Кольмских рассказов, попыткой «восстановить утраченную связь времен» ${ }^{29}$. Сославшись в выступлении на слова Марины Цветаевой, Шаламов назвал Мандельштама «первым поэтом [двадцатого М. К.] века ${ }^{30}$, а затем перешел к общей характеристике акмеизма ${ }^{31}$, в которой тоже на первый план выдвинул веру в бессмертие представителей этого течения, благодаря бессмертию их поэзии:

В этой литературной теории оказались какие-то особые жизненные силы, которые дали стихам - бессмертие, а авторам - твердость в перенесении жизненных испытаний, волю на смерть и на жизнь ${ }^{32}$.

Следует отметить, что Шаламов дал чрезвычайно высокую оценку не только творчеству Осипа Мандельштама, но и жене поэта Надежде Яковлевне, которая тоже присутствовала на вечере памяти:

Бывает время, когда живым тяжелее, чем мертвым. Надежда Яковлевна не просто хранительница стихов и заветов Мандельштама, но и самостоятельная яркая фигура в нашей общественной жизни, в нашей литературе, истории нашей поэзии. Это - также одна из важных истин, которые следует хорошо узнать участникам нашего вечера ${ }^{33}$.

Важно обратить внимание на то, что перед самым чтением рассказа на вечере памяти Шаламов произнес очень важные слова, которые можно считать ключом для раскрытия цели написания Шерри-бренди: «когда я писал его [рассказ - М. К.], я не знал, что Мандельштама все знают и так. Возможно, теперь я бы написал этот рассказ по-другому» ${ }^{34}$. Из этих слов видно, что главным обоснованием рассказа Шерри-бредни была необходимость сохранить память о поэте.

28 В письме Надежде Мандельштам писатель выразил убеждение, что «Мандельштаму будут создавать препятствия [в дороге к широкому читателю - М. К.] до конца». См. В. Шаламов, Переписка с Н. Я. Мандельитам..., с. 411.

29 См. прим. 9.

30 В. Шаламов, <О Мандельштаме> ..., с. 209.

31 См. подробнее об акмеизме: E. Papla, Akmeizm. Geneza i program, Wrocław 1980.

32 В. Шаламов, <О Мандельштаме > ..., с. 210.

33 Ibidem, c. 211.

34 В. Шаламов, <O Мандельштаме> ..., с. 211. 
Заглавие шаламовского текста, очевидно, отсылает к стихотворению Осипа Мандельштама Я скажу тебе с последней, написанного 2 марта 1931 года:

Ma voix aigre et fausse

P. Verlaine

Я скажу тебе с последней

Прямотой:

Всё лишь бредни - шерри-бренди, -

Ангел мой.

Там, где эллину сияла

Красота,

Мне из чёрных дыр зияла

Срамота.

Греки сбондили Елену

По волнам,

Ну, а мне - солёной пеной

По губам.

По губам меня помажет

Пустота,

Строгий кукиш мне покажет

Нищета.

Ой ли, так ли, дуй ли, вей ли -

Всё равно;

Ангел Мэри, пей коктейли,

Дуй вино.

Я скажу тебе с последней

Прямотой:

Всё лишь бредни - шерри-бренди, -

Ангел мой ${ }^{35}$.

35 О.Э. Мандельштам, Я скажу тебе с последней, [в:] idem, Стихи, проза, воспоминания, материальк к библиографии. Венок Мандельштаму, ред. М.М. Пришвин и др., Москва 1990, с. 336. 
Лирический герой стихотворения, подобно персонажам пушкинского Пира во время чумы (1830), тоже принимает участие в пире, но мандельштамовская чума, в отличие от «заразы» ${ }^{36}$, насылающей мрак «на самые блестящие умы» ${ }^{37}$, как несложно догадаться, это время сталинизма. Стихотворение, кажущееся на первый взгляд легким и лишенным смысла, на самом деле представляет трагедию цивилизации во время распада культуры - «срамота», «нищета» и «пустота» вытеснили наследие древнегреческой культуры ${ }^{38}$. Лирический герой ощущает время как время конца. Поэтому слова «Ангел Мэри, пей коктейли», а также дважды повторяющиеся слова «все лишь бредни - шерри-бренди», в которых проявляется борьба со страхом, следует толковать как «духовный поединок лирического героя со смертью» ${ }^{39}$.

Подобно стихотворению Осипа Мандельштама и «маленькой трагедии» Александра Пушкина, в рассказе Варлама Шаламова представлен конец культуры в виде смерти ее гениального представителя, то есть поэта. Несмотря на то, что в своем выступлении на вечере памяти автор прямо сказал, что в Шерри-бредни повествование идет о смерти Осипа Мандельштама, в тексте ни разу не упомянуто его имя. В первой строке рассказчик заявляет: «п о т [подчеркнуто мною - М. К.] умирал» ${ }^{40}$. Снаружи умирающий поэт ничем не отличается от умирающего зека - он лежит в нижнем ряду двухэтажной нары, как обычный узник; тусклый электрический свет падает лишь на его ноги. Тело выдает все признаки воздействия Колымы - голод, грязь и холод:

большие, вздутые голодом кисти рук с белыми бескровными пальцами и грязными, отросшими трубочкой ногтями лежали на груди, не прячась от холода. Раньше он совал их за пазуху, на голое тело, но теперь там было слишком мало тепла [...]. Время от времени пальцы рук двигались, щелкали, как кастаньеты, и ощупывали пуговицу, петлю, дыру на бушлате, смахивали какой-то сор и снова останавливались. [101]

В голове физически истощенного и долго пребывающего на грани жизни и смерти протагониста, переставшего понимать свою необратимую гибель, перекликаются мысли о возможной краже скрытого под головой кусочка хлеба, задержке парохода, на котором он должен быть отправлен в лагерь,

36 А. Пушкин, Пир во время чумы, [в:] idem, Малое собрание сочинений, СанктПетербург 2011, с. 646.

37 Ibidem.

38 См. О. Николенко, А. Чеботарева, Лирический герой в поэзии Осипа Мандельштама, Полтава 2010, с. 118.

39 Ibidem, c. 119.

40 В. Шаламов, Шерри-бренди, [в:] idem, Собрание сочинений..., т. 1, с. 101. Далее фрагменты текста цитируются с указанием номера страницы в квадратных скобках - М. К. 
родимом пятне на дневальном бараке, однообразии предсмертных движений, описываемых врачами. Поэт осознает, что перед лицом смерти все то, о чем он задумывается, имеет одинаковое значение: «все было равноправно - Гиппократ, дневальный с родимым пятном и его собственный грязный ноготь» [101]. Одновременно он испытывает удовольствие от сохранившейся способности думать: «приятно было сознавать, что он еще может думать [подчеркнуто мною - М. К.]» [102].

Слово «думать» неслучайно появляется шесть раз уже в первом абзаце рассказа. Мышление - это проявление душевной жизни, противоположность умирающему телу поэта. Именно через мышление проявляется жизнь, возвращающаяся время от времени: «жизнь появлялась снова, открывались глаза, появлялись мысли» [102], которые становились все глубже. Умирающий поэт «глубоко в себе» [102] ведет философское рассуждение о бессмертии: «он верил в бессмертие, в настоящее человеческое бессмертие» [102]. Он убеждён, что человеческое бессмертие вполне возможно. Смерть - это излечимая болезнь, но пока что не разгаданная, а предсмертное состояние - лишь «трагическое недоразумение» [102]. Для того чтобы жить вечно, более, чем здоровое тело, важно само желание жить, из чего вытекает, что умирающий поэт ставит душу выше тела.

Поэт предусматривает также «тютчевский» путь бессмертия:

Блажен, кто посетил сей мир

В его минуты роковые. [102]

Процитированные строки отсылают нас к стихотворению Цицерон (1836) Федора Тютчева:

Оратор римский говорил

Средь бурь гражданских и тревоги:

«Я поздно встал — и на дороге

Застигнут ночью Рима был!»

Так!.. но, прощаясь с римской славой,

С Капитолийской высоты

Во всем величье видел ты

Закат звезды ее кровавый!..

Счастлив, кто посетил сей мир

В его минуты роковые!

Его призвали всеблагие

Как собеседника на пир. 
Он их высоких зрелищ зритель,

Он в их совет допущен был-

И заживо, как небожитель,

Из чаши их бессмертье пил! ${ }^{41}$

Стихотворение Тютчева было написано как отклик на Французскую революцию, которая сравнивается с падением Римской империи, так как оба события символизируют революцию - время больших перемен, которые происходят далеко не часто, поэтому быть свидетелем крупных перемен для человека является большим вызовом, брошенный судьбой. Поэт шаламовского рассказа тоже является наблюдателем «роковых минут» в истории России - на его глазах происходит уничтожение человеческой личности тоталитарным государством; он сам является уничтоженной единицей, но оценивает себя как поэта, заслуживающего «творческое бессмертие»:

творческое-то бессмертие он заслужил. Его называли первым русским поэтом [подчеркнуто мною - М. К.] двадцатого века, и он часто думал, что это действительно так. Он верил в бессмертие своих стихов. [102]

На основании процитированного фрагмента можно полагать, что поэт вполне осознает свое место в русской поэзии и верит в свое бессмертие, благодаря своему творчеству, ибо «вся его прошлая жизнь была литературой» [102]. Ссылаясь на одно из самых глубоких писем Варлама Шаламова Надежде Мандельштам от 29 июля 1965 года, можно попытаться приблизить значение этих слов:

Поэт выражает век именно обыкновенностью своей судьбы [...]. Тут мне кажется дело не в необыкновенности, а в нравственной ответственности, которую принимает на себя поэт. Этой ответственности у обыкновенного человека нет, а для поэта она обязательна. Для России, для русской традиции во всяком случае ${ }^{42}$.

К последнему предложению хотелось бы добавить другую мысль, высказанную в статье Таблица умножения для молодых поэтов (1964): «пока кровь не выступает на строчках - поэта нет» ${ }^{43}$. Осознавая, что смерть приближается, поэт в Шерри-бренди понимает, зачем ему приходят в голову стихи, на

41 См. Ф.И. Тютчев, Цииерон, [в:] idem, Полное собрание стихотворений, Ленинград 1987, c. $104-105$.

42 В. Шаламов, Переписка с Н. Я. Мандельштам..., с. 416.

43 В. Шаламов, Таблица умножения для молодых поэтов, [в:] idem, Собрание сочинений..., т. 5, с. 11. 
первый взгляд совсем неуместны - именно в минуты смерти понимает, что представляет собой поэзия:

Жизнь входила сама как самовластная хозяйка: он не звал ее, и все же она входила в его тело, в его мозг, входила, как стихи, как вдохновение. И значение этого слова впервые открылось ему во всей полноте. Стихи были той животворящей силой, которой он жил. Именно так. Он не жил ради стихов, он жил стихами. [103]

Для героя разгадка этой последней тайны является «последней правдой»[103], которой он радуется и которая вызывает у него последний прилив вдохновения, возбуждающего мысль о сути творчества.

Творческий процесс начинается тогда, когда поэт осознает, что он представляет собой «как бы два человека - того, который запускает свою вертушку вовсю, и другого - который выбирает и время от времени останавливает запущенную машину» [103]. Весь мир очень легко переводится на язык поэзии, ибо стихи - слово. Поэт легко сочиняет очередные строфы, в которых слова подчиняются «необычайному ритму» [103]. Самое главное в стихотворчестве не умение подобрать соответствующие слова («Все [слова - М. К.] кричали: возьми меня. Нет, меня. Искать ничего не приходилось. Приходилось только отбрасывать.» [103]), а умение найти рифму, поскольку «рифма была искателем, инструментом магнитного поиска слов и понятий. Каждое слово было частью мира, оно откликалось на рифму, и весь мир проносился с быстротой какой-нибудь электронной машины» [103]. Для поэта намного важнее плода его творчества неповторимая «творческая радость» [103], с помощью которой доказывается, что „прекрасное было создано” [103].

В описании творческого процесса в рассказе имеется много сходств с личными взглядами Варлама Шаламова, которые он представил в теоретических очерках. В статье Таблица умножения для молодых поэтов писатель констатирует, что все большие русские поэты (Александр Пушкин, Михаил Лермонтов, Федор Тютчев, Александр Некрасов, Александр Блок, Марина Цветаева, Борис Пастернак и др.), в том числе и Осип Мандельштам, писали классическими размерами (ямбами), но их ямбы настолько своеобразны, что их нельзя перепутать ${ }^{44}$. В статье Поэтическая интонация (ок. 1964) Шаламов добавляет, что классическим ямбом были написаны лучшие произведения русской поэзии, например, произведения Александра Пушкина ${ }^{45}$. Сходным образом Шаламов определяет и сам творческий процесс:

44 В. Шаламов, Таблица умножения..., с. 15.

45 В. Шаламов, Поэтическая интонация, [в:] idem, Собрание сочинений..., т. 5, с. 24. 
Творческий процесс состоит больше в отбрасывании ненужного, недостаточно верного, ненадежного, мало яркого, чем в поисках. Для создания каждой строфы мир подставляет поэту мгновенно, или почти мгновенно, десятки, сотни картин прошлого, настоящего, будущего, и из этого великого множества, приведенного в создание поэта рифмой, отбрасывается или записывается некоторая часть наблюдений, знаний, иллюстраций... свободно доверяясь рифме, звуковому повтору, поэт, еще не закрепляя на бумагу, встречается с десятками направлений ${ }^{46}$.

Для более полного анализа рассказа необходимо указать на некоторое сходство теоретических взглядов Варлама Шаламова со взглядами самого Осипа Мандельштама, который в эссе Разговор о Данте (1933) утверждал:

Поэтическая речь есть скрещенный процесс, и складывается она из двух звучаний: первое из этих звучаний - это слышимое и ощущаемое нами изменение самих орудий поэтической речи, возникающих на ходу в ее порыве; второе звучание есть собственно речь, то есть интонационная и фонетическая работа, выполняемая упомянутыми орудиями ${ }^{47}$.

В Шерри-бреди творческие мысли поэта резко обрываются, когда тот начинает сомневаться в обоснованности своей творческой радости, приравнивая только что созданное произведение к последним, «поэтически беспомощным» [103] стихам Александра Блока. Отлив творческих сил в мозгу поэта проявился поразительным ощущением:

вдруг увидел недалеко от себя нечто вроде стрелковой мишени или геологической карты. Карта была немая, и он тщетно пытался понять изображенное. Прошло немало времени, пока он сообразил, что это его собственные пальцы. На кончиках пальцев еще оставались коричневые следы докуренных, дососанных махорочных папирос - на подушечках ясно выделялся дактилоскопический рисунок, как чертеж горного рельефа. Рисунок был одинаков на всех десяти пальцах - концентрические кружки, похожие на срез дерева. [104]

Таким образом, протагонист оказывается вне своего тела, представляя себе его как чужое. Размышляя над проблемами тела человека, философ Александр Грицанов утверждает:

\footnotetext{
46 В. Шаламов, Рифма, [в:] idem, Собрание сочинений..., т. 5, с. 41.

47 О. Мандельштам, Разговор о Данте, [в:] Слово и культура..., с. 108.
} 
В контексте «философии ландшафта» в предельных случаях утраты Я собственного тела может стать актуальной ситуация, когда искаженная внешняя пространственность может оказаться в состоянии придать персонажам даже иную форму (в случаях, когда тело разрушено настолько, что оно не способно организовать вокруг самое себя близлежащую жизненную предметность $)^{48}$.

Несомненно, лагерные условия полностью захватывают тело поэта. Отношение персонажа к своему телу в некоторой степени напоминает шизофреническое окаменение (pétrification) ${ }^{49}$, проявляющееся в невозможности ощущать границы собственного тела, в особом омертвлении чувства кожи. Тело поэта принадлежит не ему, а лагерю, поэтому умирающего можно назвать «человеком без кожи» ${ }^{50}$.

После того как «прошло немало времени» [104], поэт узнает на собственной коже пальцев дактилоскопический рисунок и вспоминает, как в детстве некий китаец, случайно взглянув на его ладони, объявил его «счастливцем, обладателем верной приметы» [104]. Герой рассказа действительно поверил китайцу и вспоминал его слова, когда издал свою первую книгу. Оказывается, что линию жизни поэта нельзя было предугадать, но в настоящую минуту он не испытывает никаких чувств, равнодушно воспринимая свою заканчивающуюся жизнь. Поэт осознает, что его жизнь навсегда предугадана («он был несколько раз в ссылке и знал, что он занесен в особые списки навсегда» [104]), и он не в состоянии изменить свою судьбу. Единственное, что он может сделать - умереть раньше назначенного ему десятилетнего срока. Поэт наслаждается мыслью, что он на десять лет может «обмануть» тех, кто уже распорядился его судьбой.

Персонаж испытывает очередной многочасовой прилив сил, а потом полное опустошение. Он верил в свое бессмертие: «он еще поправится» [104]. В последние часы у него то появлялось, то исчезало желание пищи, но, как оказывается, перед самой смертью последний принесенный хлеб он принял равнодушно:

он уже не волновался, не высматривал горбушку, не плакал, если горбушка доставалась не ему, не запихивал в рот дрожащими пальцами довесок, и довесок мгновенно таял во рту, ноздри его надувались, и он всем своим существом чувствовал вкус и запах свежего ржаного хлеба. А довеска уже не было во рту, хотя он не успел сделать глотка или пошевелить челюстью. Кусок хлеба растаял, исчез, и это было чудо - одно из многих

48 См. Тело, [в:] История философии. Энциклопедия, ред. А.А. Грицанов, Минск 2002, c. 1075.

49 Ibidem.

50 Ibidem. 
здешних чудес. Нет, сейчас он не волновался. Но когда ему вложили в руки его суточную пайку, он обхватил ее своими бескровными пальцами и прижал хлеб ко рту. Он кусал хлеб цинготными зубами, десны кровоточили, зубы шатались, но он не чувствовал боли. Изо всех сил он прижимал ко рту, запихивал в рот хлеб, сосал его, рвал и грыз... [105]

Хлеб - лагерное чудо - описываемый в цитируемом фрагменте как мистическое явление, перед лицом смерти переходит из сферы sacrum в сферу profanum. Потерянный интерес к хлебу, как известно, является самым сильным признаком смерти ${ }^{51}$ в лагере. Поэт понимает это и последними усилиями пытается съесть кусок, вложенный в руки, не испытывая при этом желаемого удовольствия:

поэт понял. Он широко раскрыл глаза, не выпуская окровавленного хлеба из грязных синеватых пальцев [...]. И закрыл глаза. К вечеру он умер. [105]

Поэт умирает как самый обычный доходяга, смерть которого ничего не изменяет. Его тело - уже не тело поэта, а просто тело мертвеца - послужило предметом хитрости заключенных, которые еще два дня получали хлеб «на мертвеца» [105]. Рассказчик констатирует это словами: «стало быть, он умер раньше даты своей смерти - немаловажная деталь для будущих его биографов» [105].

Таким образом, последние часы жизни поэта представлены как перекличка жизни и смерти, физических и душевных состояний, самых простых и самых глубоких мыслей, которые можно определить словами из цитированного стихотворения Я скажу тебе с последней: «бредни - шерри-бренди», однако они, как и в стихотворении, приобретают здесь глубокий смысл, поскольку на самом деле рассказ идет о сущности поэта, смысле творчества, смысле поэзии. Шерри-бренди можно рассматривать как памятник не только Мандельштаму, но и памятник тем современникам автора сборника Камень, которые в эпоху сталинизма подвергались массовому истреблению, ибо судьба Мандельштама, причисляемого Шаламовым к лучшим поэтам двадцатого века, является символом судеб многих мастеров слова, память о которых следует сохранить в коллективном сознании.

Наконец, следует отметить и то, что отношение Варлама Шаламова к Осипу Мандельштаму - это прежде всего отношение поэта к поэту, считавшего своей задачей (и одновременно нравственным долгом) сохранить имя автора сборника Камень в истории русской поэзии, выражая веру в возвра-

51 См. A. Applebaum, Gułag, пер. J. Urbański, Warszawa 2011, c. 215. 
щение его имени в «коллективную память» (Ю. Лотман) и тем самым в бессмертие его мыслей.

\section{Summary \\ «Утрачена связь времен, связь культур...» - the Memory of Osip Mandelstam in the Life and Work of Varlam Shalamov}

The author of the article reflected upon the unique role that an illustrious acmeist poet Osip Mandelstam played in the life and work of Varlam Shalamov, a representative of the socalled labour camp literature. The author analysed and interpreted the picture of the poet as well as the sub-texts of this picture in Shalamov's story Sherry brandy in the broad context of his essays and correspondance with Mandelstam's widow (Nadezhda Mandelstam). The author concluded that the issue of memory is the key to understanding Shalamov's view of Mandelstam. This issue comes to the forefront of the writer's theoretical work in which the postulate of bringing the author of the volume Stone back to the common memory was put forward on numerous occasions. The lives of Mandelstam and Shalamov are the examples of exterminating the great authors of the Soviet literature, which, in the period of Stalinism, could be compared to a laboratory where numerous experiments on "mass amnesia", that is wiping out the unwanted artists and theis works from the collective consciousness, were conducted. The author also concluded that the artistic vision of the last moments of Mandelstam's life presented in the story Sherry brandy is in fact a phylosophical reflection on the sense of being a poet. It was also concluded that the work of the poet is a centre in wchich the past, the present and the future of culture come together. The transformation and actualisation of the senses from its past (for example motives, characters, plots, values) takes place in the works of the artist, which are the present of culture, thus giving them a chance to be remembered thanks to drawing from their abundance in the future. The poet is, therefore, the source and creator of cultural memory and the durability of his works determines the immortality of his thought.

Keywords: Varlam Shalamov, Osip Mandelstam, memory, Sherry brandy, labour camp

\section{Резюме}

В настоящей статье предпринимается попытка определить место выдающегося поэта-акмеиста Осипа Мандельштама в жизни и творчестве Варлама Шаламова, представителя так называемой лагерной литературы. Анализируется и интерпретируется образ поэта и подтексты этого образа в рассказе Шерри-бренди Шаламова, в контексте его эссе и переписки с вдовой поэта Надеждой Яковлевной Мандельштам. Отмечается, что шаламовское представление о Мандельштаме неразрывно связано с проблемой памяти, выдвигающейся на первый план в теоретических статьях писателя, содержащих многочисленные требования вернуть в коллективную память имя 
автора сборника поэзии Камень. Судьба Мандельштама, как и Шаламова, является примером уничтожения великих писателей и поэтов в Советском Союзе, который в период сталинизма можно было сравнить с лабораторией для многочисленных опытов «массовой амнезии» (то есть исключения из массового сознания деятелей литературы и других видов искусства, неугодных по каким-либо причинам коммунистической власти). Художественный образ последних часов жизни Мандельштама, представленный в рассказе Шерри-бренди, на самом деле является философским рассуждением о том, в чем состоит смысл понятия «быть поэтом». Творчество представляет собой своего рода поле, на котором соединяются прошлое, настоящее и будущее культуры. В произведениях, принадлежащих к настоящему культуры, трансформируются и актуализируются смыслы из ее прошлого (например, мотивы, персонажи, ценности), оставляя тем самым надежду на дальнейшую память о них, благодаря их использованию в будущем. Таким образом, поэт - это не только хранитель, но также и создатель культурной памяти. Существование в культуре литературных произведений свидетельствует о бессмертии, вложенных в них, мыслей поэта.

Ключевые слова: Варлам Шаламов, Осип Мандельштам, память, Шерри-бренди, лагерь

\section{Streszczenie}

W artykule poddano refleksji wyjątkowe miejsce wybitnego przedstawiciela akmeizmu, Osipa Mandelsztama, w życiu oraz twórczości Warłama Szałamowa, przedstawiciela tzw. literatury łagrowej. Zanalizowano oraz zinterpretowano obraz poety i podteksty tego obrazu w opowiadaniu Sherry brandy w kontekście eseistyki oraz korespondencji Szałamowa z wdową po poecie, Nadieżdą Mandelsztam. Stwierdzono, że kluczem do zrozumienia szałamowowskiego myślenia o Mandelsztamie jest zagadnienie pamięci, wysuwające się na pierwszy plan przy lekturze esejów autora Opowiadań kołymskich, w których wielokrotnie został wysunięty postulat przywrócenia twórcy tomu Kamień do pamięci zbiorowej. Zarówno los Mandelsztama, jak i samego Szałamowa, jest przykładem unicestwiania wielkich twórców literatury w Rosji radzieckiej, którą w okresie stalinizmu można było porównać z laboratorium służącym do licznych doświadczeń „masowej amnezji” (tj. usuwania niepożądanych przez władzę twórców i ich dzieł ze świadomości masowej). Skonstatowano, że artystyczny obraz ostatnich chwil życia Mandelsztama, przedstawiony w opowiadaniu Sherry brandy, w istocie jest filozoficzną refleksją nad sensem bycia poetą. Stwierdzono, że twórczość poety stanowi swoisty ośrodek, w którym scala się przeszłość, teraźniejszość oraz przyszłość kultury. W dziełach artysty, będących wyrazem teraźniejszości kultury, dokonuje się transformacja i aktualizacja sensów z jej przeszłości (np. motywów, postaci, wątków, wartości), dając tym samym nadzieję na dalszą pamięć o nich, dzięki czerpaniu z ich bogactwa w przyszłości. Poeta jest zatem źródłem oraz kreatorem pamięci kulturowej, zaś żywotność dzieł stanowi o nieśmiertelności myśli twórcy.

Słowa kluczowe: Warłam Szałamow, Osip Mandelsztam, pamięć, Sherry brandy, łagier 


\section{Библиография}

Бродский И., Надежда Мандельштам (1899-1980). Некролог, [в:] И. Бродский, Власть стихий. Эссе, Санкт-Петербург 2012.

Вердинских В., История советской поэзии, Москва 2014.

Есипов В., Шаламов, Москва 2012.

Иванов Вяч., Шекспир и Сервантес, [в:] Вяч. Иванов, Собрание сочинений в четырех томах, т. 4, Брюссель 1987.

История философии. Энциклопедия, ред. А.А. Грицанов, Минск 2002.

Лотман Ю.М., Память в культурологическом освещении, [в:] Семиосфера, Санкт-Петербург 2010.

Лотман Ю.М., Память культуры, [в:] Семиосфера, Санкт-Петербург 2010.

Мандельштам Н.Я., Воспоминания, Москва 1987.

Мандельштам О., Разговор о Данте, [в:] Слово и культура. О поэзии. Разговор о Данте. Статьи. Рецензии, сост. П. Нерлер, Москва 1987.

Мандельштам О., Слово и культура, [в:] Слово и культура. О поэзии. Разговор о Данте. Статьи. Рецензии, сост. П. Нерлер, Москва 1987.

Мандельштам О.Э., Я скажу тебе с последней, [в:] Стихи, проза, воспоминания, материаль к библиографии. Венок Мандельштаму, ред. М.М. Пришвин и др., Москва 1990.

Нерлер П., Свидетельница поэзии. Очерк жизни и творчества Надежды Мандельштам, „Вопросы литературы” 2014, № 3.

Нерлер П., Сила жизни и смерти. Варлам Шаламов и Мандельштамы (на полях переписки Н.Я. Мандельштам и В. Т. Шаламова), „Osteuropa” 2007, № 6.

Николенко О., Чеботарева А., Лирический герой в поэзии Осипа Мандельштама, Полтава 2010.

Пушкин А., Пир во время чумы, [в:] Малое собрание сочинений, Санкт-Петербург 2011.

Тютчев Ф.И., Цицерон, [в:] Полное собрание стихотворений, Ленинград 1987.

Шаламов В., Переписка с Н. Я. Мандельштам, [в:] Собрание сочинений в шести mомах, т. 6, сост. И. Сиротинская, Москва 2013.

Шамалов В., Переписка с Ю. М. Лотманом, [в:] Собрание сочинений в шести томах, т. 6, сост. И. Сиротинская, Москва 2013.

Шаламов В., Поэтическая интонаџия, [в:] Собрание сочинений в шести томах, т. 5, сост. И. Сиротинская, Москва 2013.

Шаламов В., Рифма, [в:] Собрание сочинений в шести томах, т. 5, сост. И. Сиротинская, Москва 2013.

Шаламов В., Русские поэты и десталинизащия. Маяковский, [в:] Собрание сочинений в шести томах, т. 5, сост. И. Сиротинская, Москва 2013. 
Шаламов В., Таблица умножения для молодых поэтов, [в:] Собрание сочинений в шести томах, т. 5, сост. И. Сиротинская, Москва 2013.

Шаламов В., Шерри-бренди, [в:] Собрание сочинений в шести томах, т. 1, сост. И. Сиротинская, Москва 2013.

Шаламов В., <О Мандельштаме>, [в:] Собрание сочинений в шести томах, т. 5, сост. И. Сиротинская, Москва 2013.

Applebaum A., Gułag, пер. J. Urbański, Warszawa 2011.

Augustyn, Wyznania, пер. Z. Kubiak, Kraków 2013.

Shakespeare W., Hamlet, London 1994. 